\title{
A Response to: Assessment of Anxiety and Depression in Patients with Acne Vulgaris in Medina: A Case-Control Study [Letter]
}

\section{Barbara Falana \\ Ehigie Osebor}

Faculty of Life Sciences and Medicine, King's College London, London, UK
Correspondence: Barbara Falana Faculty of Life Sciences and Medicine, King's College London, London, UK Email Barbara.falana@kcl.ac.uk

\section{Dear editor}

We read with great interest the article by Molla et $\mathrm{al}^{1}$ exploring the assessment of anxiety and depression in patients with Acne Vulgaris in Medina. As medical students with interests in psychodermatology, particularly the impact chronic skin conditions such as Acne have on mental health outcomes, we appreciate what this article delineates and would like to suggest some changes for consideration, particularly to the study methodology, which may offer more rigorous conclusions about this topic.

Molla et al conducted a case-control study, however the overall aim was never clearly defined within the study. The reader has to infer that the aim was to establish differences in rates of anxiety and depression between those who suffered from Acne Vulgaris to those who did not. It is a triumph that the study manages to include a large age distribution (12y-60y) which ensures that results are representative and have a broad applicability. ${ }^{2}$

However, the exclusion criteria includes the "use of drugs that can exacerbate acne", which is vague and poorly defined - and risks being subjective in nature. Zohra et al's paper evaluating severity of Acne Vulgaris in patients included a range of useful and explicit drug measures such as oral contraceptive pills and iron intake. ${ }^{3}$ Furthermore, other crucial factors such as whether a patient was suffering from active malignancy, or a cosmetic related/induced acne were excluded. ${ }^{3}$ Such criteria will have been more useful in effectively eliminating unsuitable candidates for the study.

Within the study, a single dermatologist has the role of examining participants for acne grading. This runs the risk of measurement error. This can be reduced by ensuring that the dermatologist is trained to ensure they are obtaining the data in a standardised fashion. ${ }^{4}$

The use of the Global Acne Grading Score (GAGS) could also be re-considered. Whilst it is a simple and quick method, it is largely subjective and less accurate and for that reason a Lesion Counting Method is often used in the context of a clinical trial. $^{5}$

Interestingly, the study found that the prevalence of Acne was highest amongst the patients that were single, however, the discussion failed to examine why this was. Hazarika et al's paper explored the psychosocial impact of Acne Vulgaris which 
persists long after active lesions have disappeared. This can have devastating impacts on development, body perception, socialisation, and sexuality, and further, psychological issues such as lack of self-confidence, social dysfunction and an avoidance of social interactions with the opposite gender - which may be impairing this group of individuals from forming relationships and thus getting married. ${ }^{6}$

We believe these changes to the study would provide more vigorous conclusions about the relationship between anxiety and depression in patients with Acne Vulgaris in Medina and begin to form conclusions that could be modelled both nationally and internationally. Despite this, the authors are to be commended for their effort in exploring such a vital topic that is often neglected in the world of Dermatology.

\section{Disclosure}

The authors report no conflicts of interest in this communication.

\section{References}

1. Molla A, Alrizqi H, Alharbi E, Alsubhi A, Alrizqi S, Shahada O. Assessment of anxiety and depression in patients with acne vulgaris in medina: a Case-Control Study. Clin Cosmet Investig Dermatol. 2021;14:999-1007. doi:10.2147/CCID.S302311

2. Bailey R. The importance of age diversity in clinical trials [Internet]. Applied Clinical Trials Online; 2021 [cited August 7, 2021]. Available from: https://www.appliedclinicaltrialsonline.com/view/importanceage-diversity-clinical-trials. Accessed August 18, 2021.

3. Zohra T, Sultana T. Evaluation of severity in patients of acne vulgaris by global acne grading system in Bangladesh. Clin Pathol Res J. 2017;1(1):000105.

4. Alexander L, Lopes B, Ricchetti-Masterson K, Yeatts K. Sources of Systematic Error or Bias: Information Bias [Internet]. 2nd ed. North Carolina; 2015 [cited August 7, 2021]. Available from: https://sph.unc. edu/wp-content/uploads/sites/112/2015/07/nciph_ERIC14.pdf. Accessed August 18, 2021.

5. Witkowski J, Parish L. The assessment of acne: an evaluation of grading and lesion counting in the measurement of acne. Clin Dermatol. 2004;22(5):394-397. doi:10.1016/j.clindermatol.2004.03. 008

6. Hazarika N, Archana M. The psychosocial impact of acne vulgaris. Indian J Dermatol. 2016;61(5):515. doi:10.4103/00195154.190102

\begin{abstract}
Dove Medical Press encourages responsible, free and frank academic debate. The content of the Clinical, Cosmetic and Investigational Dermatology 'letters to the editor' section does not necessarily represent the views of Dove Medical Press, its officers, agents, employees, related entities or the Clinical, Cosmetic and Investigational Dermatology editors. While all reasonable steps have been taken to confirm the content of each letter, Dove Medical Press accepts no liability in respect of the content of any letter, nor is it responsible for the content and accuracy of any letter to the editor.
\end{abstract}

Clinical, Cosmetic and Investigational Dermatology

Dovepress

\section{Publish your work in this journal}

Clinical, Cosmetic and Investigational Dermatology is an international, peer-reviewed, open access, online journal that focuses on the latest clinical and experimental research in all aspects of skin disease and cosmetic interventions. This journal is indexed on CAS.
The manuscript management system is completely online and includes a very quick and fair peer-review system, which is all easy to use. Visit http://www.dovepress.com/testimonials.php to read real quotes from published authors. 